\title{
Determinants of Investment Capital Size: A Case of Small and Medium-Sized Enterprises in Vietnam
}

\author{
Vu Ngoc XUAN ${ }^{1}$
}

Received: March 09, 2020 Revised: March 28, 2020 Accepted: May 01, 2020

\begin{abstract}
This research investigates the determinants of investment capital size in Vietnam's small and medium-sized firms. The study employs a sample of 458 small and medium-sized enterprises in the country. The study is based on data collects in the areas of Hanoi, Bac Can, Buon Ma Thuot and Pleiku Provinces at time series data of October 2019. This study also identifies the factors that affect the size of investment capital in medium and small-sized enterprises in Vietnam. Data are processed via STATA 14.0 and SPSS 20.0 software. The research results indicate that (1) business lines, (2) import and export business, (3) type of business registration, (4) business location, (5) operating time, and (6) the percentage of the organization's capital contribution are factors that impact on the size of the investment capital of the business. Business line and business location have negative impacts on investment capital size. The operating time, the percentage of the organization's capital contribution, import and export business, and the type of business registration have positive impacts on investment capital size. In addition, the findings of this study also suggest that the operation time has the highest impact on investment capital size of the small and medium-sized firms in Vietnam.
\end{abstract}

Keywords : Scale of Investment Capital, Enterprises, Small and Medium-sized Enterprises, Private Companies.

JEL Classification Code: G39, G79, L81.

\section{Introduction}

Vietnam has experienced a continuous development of over $6 \%$ per year over the past 30 years. We are from a country with low income, which has now become a country with an average income of about USD3,000 per person. If measured by purchasing power, the current income per capita of Vietnam is about USD8,800. This continuous development process is largely the result of the rapid growth of businesses, especially small and medium-sized enterprises. However,

${ }^{1}$ First Author and Corresponding Author. Lecturer, Centre Director, Center for Analysis, Forecasting and Sustainable Development, National Economics University, Vietnam [Postal Address: 207 Giai Phong Road, Dong Tam Ward, Hai Ba Trung District, Hanoi, 113068, Vietnam] Email: springvnh@yahoo.com; xuanvn@neu.edu.vn

(c) Copyright: The Author(s)

This is an Open Access article distributed under the terms of the Creative Commons Attribution Non-Commercial License (http://Creativecommons.org/licenses/by-nc/4.0/) which permits unrestricted noncommercial use, distribution, and reproduction in any medium, provided the original work is properly cited. businesses in Vietnam are mostly small and very small, with diversified business structure, moderate production technology, lack of equipment, outdated equipment systems, and low labor productivity.

As a result, the number of businesses that have been gone bankrupt, dissolved or whose operations were temporarily suspended, has increased in recent years. Therefore, it is extremely important to research, find the right direction, and prepare the necessary conditions for businesses in Vietnam. In particular, investment capital plays a very important role and is the basis for the development of an enterprise; it is a condition for businesses to invest and develop, improve competitiveness, productivity and efficiency. Therefore, studying the factors and their impact on the size of the enterprise's investment capital will be an important basis for identifying solutions and making suggestions to help businesses increase the capital of their business. At the same time, coming up with the right orientation helps the state management agencies build the best business support roadmaps, and help businesses in Vietnam to grow ever stronger. 


\section{Literature Review}

When conducting research on investment, Lei and Chen (2011) stated that enterprises make direct investment when they meeting three conditions: (i) enterprises must gain comparative advantages over other businesses, such as scale, technology, marketing network, access to capital at low cost; (ii) localization, as it is more advantageous to use those advantages within the enterprise rather than subcontracting to other businesses; (iii) production in the host country since it benefits from lower costs than production abroad.

Lei and Chen (2011) also show the decision of Taiwan firms to invest in Vietnam. Hunady and Orviska (2014) identify the factors affected investment in EU countries. Jabri et al (2013) and (2015) show the determinants of investment in the MENA region. This is the basis for this paper. The theory of investment behavior of Jensen (2003) and Jouili (2018) shows that investor behavior is directly affected by: (i) changes in demand; (ii) interest rates; (iii) the level of development of the financial system; (iv) public investment; (v) human resources; vi) other investment projects in the same industry or in connected industries; (vii) the state of technology development, the ability to absorb and apply technology; (viii) the stability of the investment environment; (ix) procedural regulations; and (x) completeness of information.

Kumar (1994) referred the determinants of export of foreign products in the US. Kwiatkowski, Philips, Schmidt, and Shin (1992) used the time series to test the null hypothesis. Tran (2009) and Parker, Phan, Nguyen (2005) show the relationship between the infrastructure and investment attractiveness in Vietnam. There are some research related to investment in the world such as Loree and Guisinger (1995) who identified the determinants of United States FDI. Louail (2019), Mina (2007), Mina (2012), and Moosa (2009) refer to determinants of foreign direct investment in Arab countries. Nnadi and Soobaroyen (2015) explore the financial statement standards and FDI in Africa. Pricope (2017) and Rogmans (2013) examine FDI and adoption of international financial report standards in poor countries. Pesanran and Shin et al $(1997,1998,1999)$ show that the level of business satisfaction when investing in a country is affected by three factors: (i) group attribute about the infrastructure; (ii) group attribute of business policy and service support (SS); and (iii) group attribute of living and working environment (Xuan, Nguyen \& Ngo, 2020a). Zouita, Louail, and Mameche (2019) also mentioned the impact of national small and medium-sized enterprises on FDI attractiveness in developing countries.

Nguyen, Pham, and Nguyen (2020) referred to the impact of working capital on profitability of Vietnamese firms. Nguyen et al. (2020) also note the determinants of enterprises listed on the Vietnam Stock Exchange. Xuan (2020) looked at the main factors influencing FDI in Vietnam with evidence from technology FDI firms. Models of enterprise size are a category that reflects the size of the enterprise and the way to organize and arrange the parts that constitute the enterprise. There are many criteria for assessing the size of an enterprise, namely, scale by capital, scale by number of employees, scale by turnover, scale by profit, and so on. In Vietnam, the determination of scale enterprises comply with the provisions of the Government's Decree No. 56/2009 / ND-CP of June 30, 2009, on assistance for the development of small and medium-sized enterprises, which determines the size of enterprises mainly based on two factors - capital and labor.

Hernández, Trillo, Pagán, and Paxton (2005) showed that the type of business, the age of business owner, and the number of capital contributors are factors affecting the firm's size. Meanwhile, Colombo and Grilli (2005) said that the business activities, the type of import-export business, and the number of founding members have significant explanatory power in the model of factors affecting the size of enterprise capital. Xuan (2020) further pointed out that the size of firm capital is affected by the organization's capital contribution, number of employees and the rate of return on total assets of the industry. The gender and age of the person who has the decision-making role in the enterprise also has a certain impact on the size of the business.

With studies on Vietnam, Xuan et al. (2020a) argued that the business sector, type of export or domestic business, and the form of business registration have a close relationship with the size of the business capital. According to Xuan, Nguyen, and Ngo (2020b), factors of lines of business, type of business registration, location of production and business establishments, operating time of enterprises, and percentage of capital contribution of the organization in the capital structure of the business are the factors that affect the size of the capital of the business. Based on the above findings, our research model on factors affecting the capital size of enterprises in Vietnam is constructed as follows (Figure 1):

Regression model of factors affecting the size of $\mathrm{L}$ local enterprises Vietnam table has the following:

$Q M V=\beta 0+\beta 1 * N G A N H N G H E+\beta 2 * X N K H A U+$ $\beta 3 *$ LOAIHINH $+\beta 4 *$ VITRI $+\beta 5 *$ GIOITINH $+\alpha 1 *$ THOIGIAN $+\alpha 2 *$ TUOI $+\alpha 3 *$ SOTHANHVIEN $+\alpha 4 *$ $V O N G O P+\alpha 4 * V O N G O P+\alpha 4 * V O N G O P+L A O D O N G$ $+\alpha 6 R O A+e i$

In which: QMV - dependent variable (million dong) is the size of the enterprise; NGANHNGHE (dummy variable) represents the business line of the enterprise, whether it 


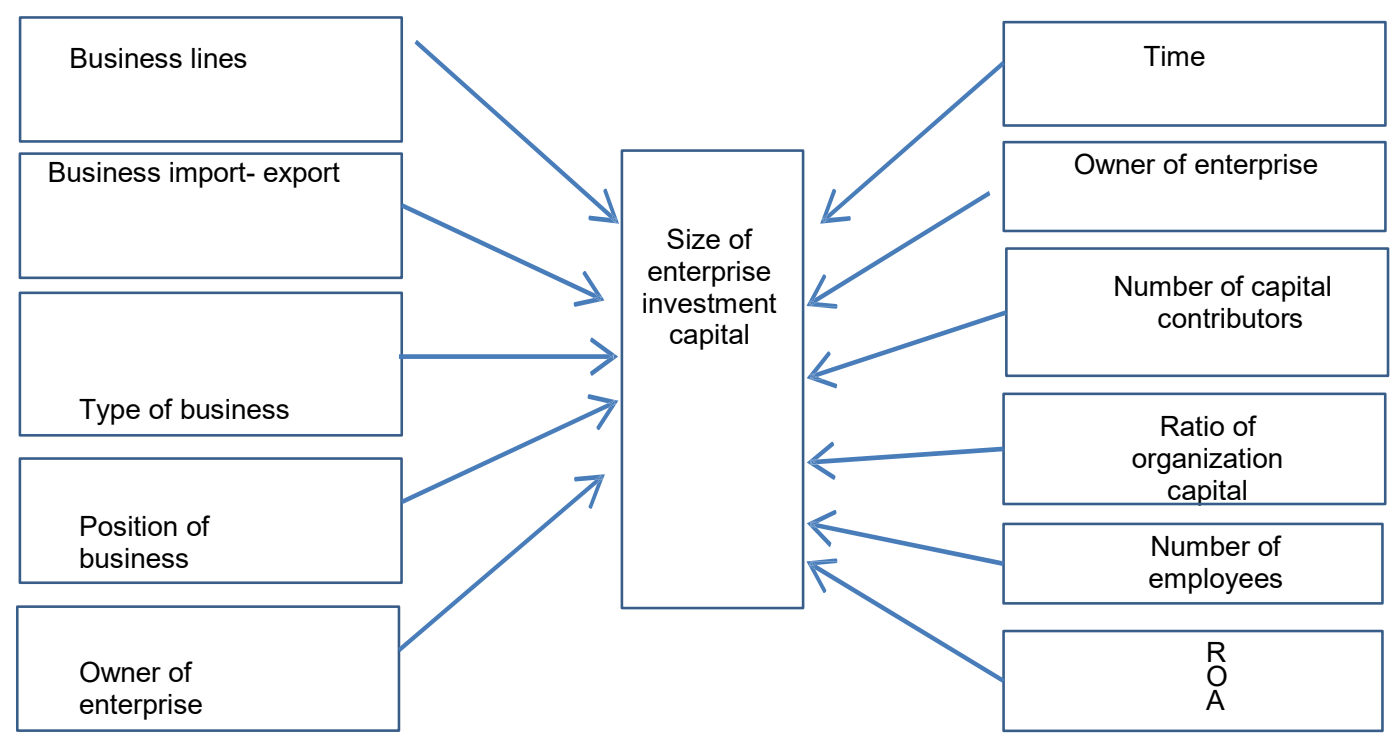

Figure 1: Determinants of the enterprise's investment capital size

is construction industry, service trade or agroforestry; XNKHAU (dummy variable) shows whether the business has an import-export business; LOAIHINH (dummy variable) represents the type of business, is a limited liability company (Limited), one member limited liability company, joint stock company or private enterprise; VITRI (dummy variable) represents the location of business operations in urban or rural areas; GIOITINH (dummy variable) represents the gender of the business owner or the decisive person in the business; THOIGIAN (years) shows the operating time of the business from the beginning of operation; TUOI (age) represents the age of the business owner or the decisive person in the business; SOTHANHVIEN (person or organization) represents the number of founding members, contributing capital to the enterprise plus the number of organizations contributing capital to the enterprise; VONGOP (\%) represents the proportion of the organization's capital contribution to the total capital structure of the enterprise; LAODONG (person) represents the number of employees currently in the enterprise; ROA $(\%)$ represents the ratio of profit to assets of the business.

\section{Research Methodology}

The research runs a multivariate regression model with secondary data provided from the Department of Planning and Investment and the Tax Department of Vietnam. The study uses the Stata and SPSS tool to run regression models and carry out relevant tests to determine the suitability and extent of factors affecting the capital size of enterprises.

The source of research data for all variables is extracted from enterprise data at the Vietnam Tax Department and the
Department of Planning and Investment of Hanoi, Bac Can, Buon Me Thuan and Pleiku in October 2019. The total number of enterprise data taken from these agencies up to December 31,2019 , selected by the author, consists of 458 small and medium-sized enterprises. The business data set will be examined to eliminate the samples that do not have enough data according to the study variables (e.g., lack of representative gender, lack of business lines, etc.), and eliminate samples that are too large to risk affecting the research.

\section{Results}

\subsection{Model Testing}

\subsubsection{Testing Autocorrelation and Multi-Collinearity}

The results of correlation analysis between the independent variables show that the value of the correlation coefficients is very low and even smaller than 1 . This shows that the independent variables are not closely correlated with each other, i.e., there is no multi-collinear phenomenon in the model. The time variables, the number of founding members, the contributed capital of the organization and the labor are correlated with the higher dependent variables. The age and ROA variables have very low correlation with the dependent variable. One can predicts it is likely that these variables have no significant impact on the dependent variable in the model.

Correlation analysis between the independent variables showed that there is no polynomial in the model. However, it is also necessary to test the multi-collinearity phenomenon 
through the variance inflation factor (VIF) to really confirm whether the independent variables interact with each other or not. The results of VIF analysis show that all VIF coefficients of the variables are less than 10 . This means that the independent variables have no linear correlation with each other and therefore no present polymorphism in the model.

\subsubsection{Regression Results and Testing of Regression Coefficient}

The results of the first regression model show that with a $5 \%$ significance level, GIOITINH variables with $\mathrm{P}$-value $=$ 0.5050 , TUOI variables with $P$-value $=0.299$, variables

SOTHANHVIEN with P-value $=0.3162$, LAODONG with $\mathrm{P}$-value $=0.2093$ and $\mathrm{ROA}$ with $\mathrm{P}$-value $=0.33021$ have no explanations in the model. The remaining variables are meaningful to explain in the model with $5 \%$ significance level (i.e. P-value $<0.05$ ) or $10 \%$ (i.e. P-value $<0.1$ ). Variables that do not make sense in the model are GIOITINH, TUOI, SOTHANHVIEN, LAODONG, ROA can only be removed from the model when the Wald test confirms that half of these variables have no meaningful explanation in the tissue. Table 1 shows the result of the Wald test which results in the following:

The result of un-variables test showed the coefficient $\mathrm{F}$ $=1.01$ with $\mathrm{P}-$ value $=0.4093$. This means that, with the $5 \%$ significance level, the regression coefficient hypothesis of the variables GIOITINH, TUOI, SOTHANHVIEN, LAODONG, ROA, simultaneously equal to 0 , means that these five variables have no explanatory power and can be removed from the model. Unexplained variables are removed from the model and the regression is run for a second time. The results are as follows (see Table 2)

\section{Test of Model Suitability}

The second regression results in Table 2 test the suitability of the model with the $\mathrm{F}$ test (analysis of variance). The performed $\mathrm{F}$ - test shows that the value of $\mathrm{F}=321.8327$ and that the $\mathrm{P}$ - value coefficient of this test is equal to 0.0000 , which means that the research model is perfectly suitable. With the above $\mathrm{F}$ - test results, the coefficient $\mathrm{R}$ squared $=$ 0.657772 and $\mathrm{R}$ squared corrected $=0.655728$ is completely meaningful. This means that the remaining nine independent variables in the model explained $65.77 \%$ of the change in firm's capital size.

\subsection{Testing the Lack of Variables}

After the results of testing the suitability of the model, nine independent variables still have significant impact on the dependent variable. However, the R-squared coefficient indicates that the independent variables only explain $65.77 \%$ of the change in the value of the dependent variable. Therefore, it is likely that the model is missing variables. Ramsey's test considers that the lack of a model variable results in a hypothetical variable FITTED ${ }^{\wedge} 2$ with $\mathrm{P}$ - value $=0.8702$ and FITTED $\wedge$ 3 with $\mathrm{P}-$ value $=0.7756$, which is not significant to explain a significance level of $5 \%$ due to $\mathrm{P}$ - value $>0.05$. This means the model is not missing variables. The explanatory level of $65.77 \%$ of the significant variables in the model on the dependent variable is completely acceptable, and no variables need to be added to the model.

\subsection{Constant Variance}

The White test results determine the variance for the results as follows. With the above test results, the test of $\mathrm{F}$ coefficient $\mathrm{R}$ squared of the error variance has $\mathrm{P}$

Table 1: Null Hypothesis Results- Test WALD

\begin{tabular}{|c|c|c|c|}
\hline Test Statistic & Value & df & Probability \\
\hline F-statistic & 1,011598 & $(5,1502)$ & 0,4093 \\
\hline Chi-square & 5,057990 & 5 & 0,4088 \\
\hline \multicolumn{4}{|c|}{ Null Hypothesis: $C(8)=C(10)=C(11)=C(13)=C(14)=0$} \\
\hline \multicolumn{4}{|c|}{ Null Hypothesis Summary: } \\
\hline Normalized Restriction $(=0)$ & & Value & Std. Err \\
\hline C(8) - GIOITINH & & $-158,7821$ & 238,1286 \\
\hline$C(10)-T U O I$ & & 15,07331 & 14,53569 \\
\hline C(11) - SOTHANHVIEN & & 159,0203 & 158,5992 \\
\hline $\mathrm{C}(13)$ - LAODONG & & $-7,119794$ & 5,668643 \\
\hline$C(14)-\mathrm{ROA}$ & & $-35,68519$ & 34,57031 \\
\hline
\end{tabular}


Table 2: The Results

\begin{tabular}{|c|c|c|c|c|}
\hline Variable & Coefficient & Std. Error & t-Statistic & Prob. \\
\hline CNXD & $-1761,724$ & 399,8631 & $-4,405817$ & 0,0000 \\
\hline TMDV & $-6653,091$ & 445,1319 & $-14,94634$ & 0,0000 \\
\hline XNKHAU & 6057,536 & 345,4565 & 17,53488 & 0,0000 \\
\hline CTCP & 1399,502 & 458,4059 & 3,052976 & 0,0023 \\
\hline $\mathrm{TNHH}$ & 1065,268 & 411,1743 & 2,590795 & 0,0097 \\
\hline TNHHMTV & 1462,253 & 382,0204 & 3,827683 & 0,0001 \\
\hline VITRI & $-675,0235$ & 236,1277 & $-2,858723$ & 0,0043 \\
\hline THOIGIAN & 306,8592 & 67,24897 & 4,563032 & 0,0000 \\
\hline VONGOP & 12,70034 & 3,695869 & 3,436360 & 0,0006 \\
\hline $\mathrm{C}$ & 6076,576 & 656,9985 & 9,248994 & 0,0000 \\
\hline R-squared & 0,657772 & Mean dependent var & \multicolumn{2}{|c|}{6272,531} \\
\hline Adjusted R-squared & 0,655728 & S.D. dependent var & \multicolumn{2}{|c|}{7266,497} \\
\hline S.E. of regression & 4263,595 & Akaike info criterion & \multicolumn{2}{|c|}{19,56018} \\
\hline Sum squared resid & $2,74 \mathrm{E}+10$ & Schwarz criterion & \multicolumn{2}{|c|}{19,59528} \\
\hline Log likelihood & $-14826,40$ & Hannan-Quinn criter. & \multicolumn{2}{|c|}{19,57325} \\
\hline F-statistic & 321,8327 & Durbin-Watson stat & \multicolumn{2}{|c|}{1,957420} \\
\hline Prob(F-statistic) & 0,000000 & & & \\
\hline
\end{tabular}

Table 3: Test Results of Variations - White Test

\begin{tabular}{|l|l|l|l|}
\hline \multicolumn{1}{|c|}{ F-statistic } & $\mathbf{6 , 0 4 1 7 5 2}$ & Prob. F(42,1474) & $\mathbf{0 , 1 3 3 2}$ \\
\hline Obs $^{*}$-squared & 222,8004 & Prob. Chi-Square(42) & 0,1324 \\
\hline Scaled explained SS & 542,9935 & Prob. Chi-Square(42) & 0,0005 \\
\hline
\end{tabular}

value - value $=0.1332>0.05$. This shows that, at the $5 \%$ significance level, the variance hypothesis is accepted. The error of the variables in the model is constant, meeting the existing requirements of the regression model (see Table 3).

\subsection{Regression Model Results after the Test}

According to the original research model, the first regression model was estimated with 14 independent variables. After performing the tests, it is possible to conclude that the regression estimates of the remaining nine independent variables in the second regression model reflect the change in the value of the dependent variable. Specifically, the estimated results of the model are as follows:

$\mathrm{QMV}=6,076-1,761 * \mathrm{CNXD}-6,653 * \mathrm{TMDV}+$ $6,057 *$ XNKHAU $+1,399 * \mathrm{JSC}+1,065 *$ Limited

$+1,462 *$ TNHHMTV $-675^{*}$ VITRI $+306 *$ THOIGIAN + $12 *$ VONGOP
The results of the study are explained with the following significant variables:

R-square coefficient: $65.77 \%$. All significant factors in the above model explain $65.77 \%$ of the change in capital size of the business.

Blocking factor of the model: 6,076; this means that under normal conditions, without the impact of factors, the capital size of enterprises in Vietnam is 6,076 million VND.

Regression coefficient of constructional variables: The value of this coefficient is equal to $-1,761$, which means that without considering the impact of the remaining variables, the capital size of enterprises in the construction industry is low than the scale of businesses in the field of agriculture and forestry 1,761 million. The above result is also completely consistent with the conditions in Vietnam. Agroforestry and afforestation enterprises in Vietnam often need very large land areas, up to several hundred or thousands of hectares, so the scale of capital of these businesses is very large, mainly consisting of capital for renting land. The construction works in Vietnam are mainly small ones, the processing industry 
is mainly preliminary, and the mining industry is mainly quarrying. Therefore, the capital available to these enterprises is often not as high as that of agro-forestry enterprises.

Regression coefficient of trade and service variable: The value of this coefficient is equal to $-6,653$ which means that the capital size of enterprises in the service trade is less than the capital of enterprises in the agriculture and forestry sector million dong. The result is also completely consistent with real conditions in Vietnam. Commercial enterprises in Vietnam are mainly trading in small-scale agricultural products and goods; tourism services are expected to have a large capital scale, but in fact have not implemented many large-scale projects. Therefore, the capital for these enterprises in Vietnam is usually not as high as that for agroforestry enterprises.

Regression coefficient of XNKHAU variable: The value of this coefficient is 6.057 , meaning that enterprises with import and export business have capital scale larger than those without import- export scale have and export business, copper. Export businesses have a larger capital size than the rest due to the need for more capital to meet the requirements of investing, purchasing raw materials, hiring more workers to best meet the needs import and export orders.

Regression coefficients of variables JSC, Ltd,

Ltd MTV: The values of these coefficients are 1,339, 1,065 , and 1,462 , respectively. It means that the capital size of the enterprises in the form of joint stock companies, limited liability companies, and one-member limited liability companies has a larger capital scale than those of private enterprises $-1,399,1,065$, and 1,462 million, respectively.

The fact also shows that businesses operating in the form of joint stock companies and limited liability companies can call for capital from more sources to increase scale. Statistical results also show that in Vietnam, the average capital size of enterprises by joint stock company type is the highest.

Regression coefficient of the VITRI variable: The value of coefficient this is equal to -675 , meaning that enterprises located in urban areas will have a smaller capital scale than those located in the area rural area 675 million. Although different from previous studies, this research result has certain relevance in Vietnam. Rural enterprises often invest in agriculture, forestry, mining and often large-scale, while urban enterprises are often small and construction enterprises with the scale are negligible. Therefore, the results show a clear difference in scale between the two groups of enterprises operating in rural and urban areas.

The regression coefficient of the THOIGIAN variable: The value of this coefficient is equal to 306 , meaning that the time the business operations increase by one year, the capital size increases to VND 306 million. The reality in Vietnam shows that the longer the business is in operation, the more it tends to supplement capital or retain part of the profits to expand production and business.

Regression coefficient of VONGOP variable: The value of this coefficient is 12 which means that the capital contributed by organizations to the enterprise increased by $1 \%$ in the total capital structure of the enterprise, then the size of the enterprise increased to 12 million VND. In fact, in Vietnamese enterprises and all Vietnamese enterprises in general, the capital contribution and investment from organizations is always a strong financial resource to enterprises operate.

Large businesses tend to open subsidiaries or contribute capital to other companies to expand and diversify their portfolios. The capital of companies and corporations is always much greater than the capital from individuals. Therefore, businesses that can mobilize this investment will be able to significantly increase capital to run production and business activities. The results of the study are explained with the following non-significant variables:

Regarding gender of business owners: In the current development context, there is very little difference between male and female leaders, as the gap in qualifications and experience of men and women increasingly getting smaller. In addition, the majority of enterprises in the form of onemember limited liability in Vietnam are subsidiaries of another. Funding for subsidiaries is often decided by the parent company. Meanwhile, the type of joint-stock company or limited decision is usually based on the collective opinion of the members rather than the legal representative.

About the number of capital contributors/founders: In Vietnam, the statistics show that joint-stock companies have an average number of members nearly 1.5 times that of a limited company, but the size of capital is negligible. In addition, a one-member limited liability company (mainly a subsidiary of another enterprise) has a larger capital scale than the limited liability company. Therefore, given the specific conditions in Vietnam as above, the number of founding members / capital contributors has no impact on the size of the business.

Regarding the ratio of profit to total assets, enterprises in Vietnam tend to report lower profits to reduce corporate income tax. The statistical results also show that the level of profitability of enterprises in all three industries, agriculture and services is low, and there is no big gap, ranging from 2.8 to $3 \%$. Therefore, the ratio of profit to total assets does not reflect the actual capital size of the business.

Regarding the age of the owner/decision-making person in the enterprise: One-member limited companies in Vietnam are mostly subsidiaries of another enterprise, so the decision power often falls into parent companies. For limited liability companies or joint-stock companies, most decisions are made by the general meeting of shareholders or members. Private enterprises are mostly small, the size of enterprises often depends on their own capital. 
Regarding the number of employees in the enterprise: It is typical in Vietnam that high-capital enterprises are agroforestry projects. However, forestry and afforestation projects in Vietnam cover hundreds of hectares, but do not need a lot of regular labor, only agricultural projects need a lot of labor resources. In contrast, commercial services projects that have a small capital size may also require much or little labor. Transport enterprises often need a lot of labor, while the size of labor in commercial enterprises is very small. The above analysis shows that the labor force of enterprises has almost no relationship with the capital source of enterprises in Vietnam.

\section{Conclusion and Policy Recommendations}

\subsection{Conclusions}

With the determination of factors and the quantifying of their respective impacts on the size of capital of Vietnamese enterprises, we make the following observations:

First, businesses operating in the sectors of agricultural and forestry often have larger capital size than those in other areas that need a lot of capital. Therefore, Vietnam needs to come up with practical solutions to solve capital constraints for businesses, to promote investment and operational efficiency of enterprises in this field, and increase resources capital.

Second, import-export businesses have a larger capital size than the rest due to the need for more capital to meet import and export orders. Therefore, attention needs to be paid to capital priority programs for import-export enterprises in the future.

Third, enterprises in the form of limited liability and onemember limited liability companies are larger than private enterprises. This result implies that Vietnam should have policies to encourage private enterprises to expand, to enter into joint production with each other in the form of shares or limited liability to increase capital, enlarge production scale export.

Fourth, rural enterprises have a larger working capital than enterprises in urban areas. Therefore, Vietnam needs to pay attention to the implementation of solutions to improve production and business conditions in rural areas and not just focus on urban areas.

Fifth, the longer the enterprises have been in operation, the larger the scale of capital. Vietnam needs to have strong solutions in solving procedures related to investment licensing, so that enterprises can go into operation, quickly replenish capital sources, and boost production and business efficiency.

Sixthly, the size of businesses increases as they receive capital contribution and investment from other businesses and organizations. Therefore, besides private capital investment, the country needs to have solutions to call businesses and organizations to invest strongly in Vietnam.

\subsection{Policy Implications}

From the aforementioned analysis results, the State management agencies of Vietnam need to take practical actions to promote the increase of capital for businesses. Such a measure will accelerate the growth in of investment capital in Vietnam. Some policy suggestions for the near future are:

Firstly, promoting the development and implementation of priority policies for agricultural development. Research results have shown that the agricultural sector has a large capital scale and is dominant compared to other industries, but the lowest number of enterprises operates there. Speeding up the development of this industry will attract a huge amount of capital for Vietnam's development. In addition, the development of agriculture is one of the important prerequisites for the development of agro-processing industries and trade of agricultural products.

Secondly, promoting the development and implementation of priority policies for import and export businesses. Import and export should be considered as one of the priority areas in Vietnam's economic management policy because it brings more added value. The capital demand of these enterprises is very large. Therefore, the capital priority programs for importexport enterprises need to be given full attention to in the future.

Thirdly, promoting private enterprises to link production will help one-member limited company to expand capital to get advantages thanks to scale. Research results show that traditional businesses limited, limited liability and onemember limited liability are larger than private enterprises. The small production capital of these private enterprises is one of the causes leading to bankruptcy and production shutdown due to lack of capital.

Fourth, promote investment in developing transport and rural infrastructure to support connecting businesses. Research results have shown that enterprises located in rural areas have a larger operating capital scale than those in urban areas. Therefore, Vietnam also needs to pay attention to the implementation of solutions to improve production and business conditions in rural areas to facilitate a better operation for businesses in this area instead of just focusing on urban areas like today.

Fifth, accelerate the investment process and operation licensing schedule for businesses. In fact, there are many businesses in Vietnam that take a long time to be appraised to issue registration certificates or investment certificates. Therefore, Vietnam needs to have strong solutions in handling procedures related to operating licenses for 
businesses to operate, quickly replenish capital, and boost operational efficiency manufacturing business.

Sixth, to call for investment capital from organizations, enterprises and large investors. Research results have shown that the increase in enterprises' capital contribution increases the size of enterprises. In addition to private investment, Vietnam needs to have solutions to call businesses and organizations to invest strongly in Vietnam. This type of capital contribution will help enterprises when forming a financial capacity strong enough to ensure the operation of production and business activities more effectively.

Besides the efforts of state agencies, enterprises in Vietnam also need to take specific actions, so that state policies can take effect. Issues raised for businesses are:

Firstly, small private enterprises speed up the process of put production in common with others, merging and operating in the form of shares and limited liability to have large production capital, ensuring better operation and production, large scale, cost savings and increased profits.

Second, businesses that are setting up and prepare projects should focus on coordinating with the government in addressing land issues, environmental protection, ground clearance, etc., to accelerate, put businesses into operation quickly, and minimize the time the capital remains stagnant because it cannot operate.

Thirdly, rural businesses need to coordinate more closely with the State and be more proactive in investing in infrastructure in their project areas and enterprises, avoiding the psychology of being too dependent on government incentives.

Fourth, businesses should proactively approach and call for capital contribution from large enterprises and organizations instead of waiting for capital from credit institutions. The financial potential and management experience of large capital enterprises will greatly support small businesses in the process of production and business as shareholders and contributors.

\section{References}

Colombo, M. G., \& Grilli, L. (2005). Start up size - The role of external financing. Economic Letters, 88(2), 243-250. https:// doi.org/10.1016/j.econlet.2005.02.018

Hernández-Trillo, F., Pagán, J. A., \& Paxton, J. (2005). Star up capital. Microenterprises and technical efficiency in Mexico. Review of Development Economics, 9(3), 434-447. https://doi. org/10.1111/j.1467-9361.2005.00286.x

Jabri, A., \& Brahim, M. (2015). Institutional determinants of foreign direct investment in MENA region: Panel co- integration analysis. Journal of Applied Business Research, 31(5), 20012012. DOI:10.19030/jabr.v31i5.9417

Jabri, A., Guesmi, K., \& Abid, I. (2013). Determinants of foreign direct investment in MENA region: Panel co-integration analysis. The Journal of Applied Business Research, 29(4), 1103-1109. DOI:10.19030/jabr.v29i4.7976

Jensen, N. M. (2003). Democratic governance and multinational corporations: Political regimes and inflows of foreign direct investment. International Organization, 57(3), 587-616. DOI: $10.1017 /$ S0020818303573040

Jouili, T. (2018). Determinants of foreign investment in maritime nations. International Journal of Advanced and Applied Sciences, 5(5), 43-47. DOI:10.21833/ijaas.2018.05.006

Kumar, N. (1994). Determinants of export orientation of foreign production by US multinationals: An inter-country analysis. Journal of International Business Studies, 25(1), 141-156. DOI:10.1057/palgrave.jibs.8490196

Kwiatkowski, D., Phillips, P. C., Schmidt, P., \& Shin, Y. (1992). Testing the null hypothesis of stationary against the alternative of a unit root: How sure are we that economic time series have a unit root? Journal of Econometrics, 54(1-3), 159-178. DOI:10.1016/0304-4076(92)90104-Y

Lei, H. S., \& Chen, Y.S. (2011). The right tree for the right bird: Location choice decision of Taiwanese firms' FDI in China and Vietnam. International Business Review, 20(3), 338-352. DOI:10.1016/j.ibusrev.2010.10.002

Loree, D.W., \& Guisinger, S. E. (1995). Policy and non-policy determinants of US equity foreign direct investment. Journal of International Business Studies, 26(2), 281-299. DOI:10.1057/ palgrave.jibs. 8490174

Louail, B. (2019). Determinants of foreign direct investment in Arab countries during 1970-2016. International Journal of Advanced and Applied Sciences, 6(3), 102-110. DOI:10.21833/ ijaas.2019.03.015

Mina, W. M. (2007). The location determinants of FDI in the GCC countries. Journal of Multinational Financial Management, 17(4), 336-348. DOI:10.1016/j.mulfin.2007.02.002

Mina, W. M. (2012). The institutional reforms debate and FDI flows to the MENA region: The "best" ensemble. World Development, 40(9), 1798-1809. DOI:10.1016/j.worlddev.2012.04.026

Moosa, I.A. (2009). The determinants of foreign direct investment in MENA countries: An extreme bounds analysis. Applied Economics Letters, 16(15), 1559-1563. DOI:10.1080/13504850701578819

Nguyen, A. H., Pham, H. T., \& Nguyen, H. T. (2020), Impact of Working Capital Management on Firm's Profitability: Empirical Evidence from Vietnam. Journal of Asian Finance, Economics and Business, 7(3), 115-125. https://doi.org/10.13106/ jafeb.2020.vol7.no3.115

Nguyen, T. N. L., \& Nguyen, V.C. (2020). The Determinants of Profitability in Listed Enterprises: A Study from Vietnamese Stock Exchange. Journal of Asian Finance, Economics and Business, 7(1), 47-58. https://doi.org/10.13106/jafeb.2020. vol7.no1.47

Nnadi, M., \& Soobaroyen, T. (2015). International financial reporting standards and foreign direct investment: The 
case of Africa. Advances in Accounting, 31(2), 228-238. DOI:10.1016/j.adiac.2015.09.007

Parker, S., Phan, V. Q., \& Nguyen, N. A. (2005): Has the USVietnam Bilateral Trade Agreement Led to Higher FDI into Vietnam? International Journal of Applied Economics, 2(2), 199-223.

Pesaran, M. H. (1997). The role of economic theory in modelling the long run. The Economic Journal, 107(440), 178-191. DOI:10.1111/1468-0297.00151

Pesaran, M. H., \& Shin, Y. (1998). An autoregressive distributedlag modelling approach to cointegration analysis. Econometric Society Monographs, 31, 371-413. DOI: 10.1017/ CCOL521633230.011

Pesaran, M. H., Shin, Y., \& Smith, R. P. (1999). Pooled mean group estimation of dynamic heterogeneous panels. Journal of the American Statistical Association, 94(446), 621-634. DOI:10.10 80/01621459.1999.10474156

Pesaran, M. H., Shin, Y., \& Smith, R.J. (2001). Bounds testing approaches to the analysis of level relationships. Journal of Applied Econometrics, 16(3), 289-326. DOI: 10.1002/jae.616

Pricope, C. F. (2017). The implications of IFRS adoption on foreign direct investment in poor countries. The Audit Financial Journal, 15(146), 218-218. DOI:10.20869/AUDITF/2017/146/218
Rogmans, T. (2013). Location and operation mode decision making in the Middle East: A case study approach. Journal of Strategy and Management, 6(2), 190-206. DOI: $10.1108 / 17554251311322440$

Tran, T. Q. (2009). Sudden Surge in FDI and Infrastructure Bottlenecks: The Case in Vietnam. ASEAN Economic Bulletin, 26(1), 58-76. https://www.muse.jhu.edu/article/266539.

Xuan, V. N. (2020). Factors affecting foreign direct investment: Evidence at foreign technology enterprises in Vietnam. International Journal of Advanced and Applied Science, 7(4), 21-28. DOI: 10.21833/ijaas.2020.04.004

Xuan, V. N., Nguyen, T. P. T., \& Ngo, T. A. (2020a). Factors affecting support services in small and medium enterprises: Evidence from Vietnam small and medium information technology enterprises. Management Science Letter, 10(4), 303-312. DOI:10.5267/j.msl.2019.9.001

Xuan, V. N., Nguyen, T. P. T., \& Ngo, T. A. (2020b). Factors affecting the business performance of enterprises: Evidence at Vietnam small and medium-sized enterprises. Management Science Letters, 10(4), 865-870. DOI:10.5267/j.msl.2019.10.010

Zouita, M.S., Louail, B., \& Mameche, Y. (2019). The impact of the local SMEs sector on FDI and the mediating effect of IFRS adoption in developing economies: The case of Algeria. International Journal of Advanced and Applied Sciences, 6(11), 120-129. DOI:10.21833/ijaas.2019.11.015 